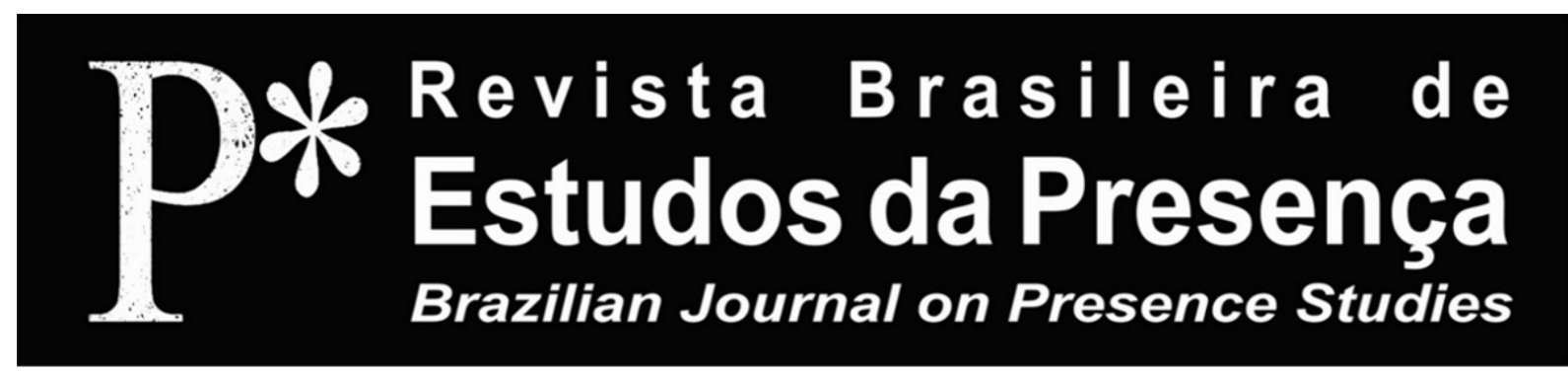

DOI - http://dx.doi.org/10.1590/2237-266037219

ISSN 2237-2660

\title{
Portas EntreAbertas: um relato etnográfico a partir de um fazer teatro com pessoas privadas de liberdade - para além do espetáculo...
}

\author{
Micael Côrtes \\ Universidade Federal do Acre - UFAC, Rio Branco/AC, Brasil
}

RESUMO - Portas EntreAbertas: um relato etnográfico a partir de um fazer teatro com pessoas privadas de liberdade - para além do espetáculo... - Este texto tem como objetivo relatar etnograficamente uma experimentação a partir de uma oficina intitulada $O$ Brincar com Teatro, desenvolvida em um contexto presidiário entre 2008 a 2009 segundo a visão de um observador-participante em um galpão denominado Escola do Presídio, situado no interior do estado de Sáo Paulo, junto ao grupo de monitores culturais detentos. Trata-se, portanto, de possibilitar um olhar para o campo da Pedagogia do Teatro: teatro-educaçáo enquanto uma aprendizagem que favoreça um processo artístico-estético-pedagógico na possibilidade de contemplar a criaçáo, a imaginação, os sentimentos, as emoções, as paixóes, as tragédias e a ludicidade como uma aventura para ampliar um conhecimento aberto e sensível dessa área e, então, para torná-la uma experiência educativa.

Palavras-chave: Pedagogia do Teatro. Teatro-Educação. Etnografia. Experiência Estética.

ABSTRACT - Half-opened Doors: an ethnographic account from a drama play with prison inmates - beyond the show... - This paper aims to ethnographically report an experiment from a workshop entitled Playing with Theater, which was developed in a prison context from 2008 to 2009 as an observer-participant in a shed known as Escola do Presídio (Prison School), in the countryside of the State of São Paulo, together with the cultural group monitors inmates. It urges us a gaze to the field of Theatre Pedagogy: theater-education as a learning process which provides an artistic-aesthetic-pedagogical experience as a possibility to contemplate the creation, the imagination, the feelings, the emotions, the passions, the tragedies, and recreation as an adventure to broaden an open and sensitive knowledge of this area, and then make it an educational experience.

Keywords: Production of Knowledge. Theatre Pedagogy. Theatre Education. Ethnography. Aesthetic Experience.

RÉSUMÉ - Les Porte Semi-ouvertes: um compte ethnographique, un drame avec le personnes privés de liberté- en plus du spéctacle... - Ce texte a pour but de signaler une expérimentation ethnographique d'un atelier intitulé Jouer avec le Théâtre développée dans un contexte prisonnier de 2008 à 2009 en tant que observateur-participant dans un hangar, connu comme École Prison dans l'état de Sáo Paulo par les détenus du groupe culturel de moniteurs. Il est, par conséquent, afin de permettre un regard sur le domaine de la Pédagogie du Théâtre: théâtre-éducation, tout en apprenant un processus qui favorise artistique, esthétique et pédagogique que vous pourrez contempler la création, l'imagination, les sensations, les émotions, les passions, les tragédies et le jeux comme une aventure pour effectuer une ampleur sur une connaissance ouverte sensible dans ce domaine vers l'expérience éducative. Mots-clés: Pédagogie du Théâtre. Théâtre-Éducation. Ethnographie. L'Expérience Esthétique. 


\section{Portas EntreAbertas do Presídio - para/ou além do espetáculo...}

Francis Bacon publica o Novum Organum, o novo sistema do conhecimento humano, cujo frontispício original de 1620 se encontra expresso no seu entender sobre o avanço do conhecimento humano: entre os pilares representando as colunas de Hércules, o navio do conhecimento faz-se ao mar encapelado, em direcção a terras desconhecidas, para delas trazer a preciosa carga de novos conhecimentos. Para trás do navio ficam as margens e as terras conhecidas do Mediterrâneo; a figura é, pois, uma metáfora da transição para um novo mundo, com a sua promessa de mais e maiores riquezas (Caraça, 1991, p. 38).

Parto dessa citação acima para aventura-me na produção de conhecimento e, assim, possibilitar contribuiçôes para o campo da Pedagogia do Teatro a partir das minhas questôes, dos desejos, dos saberes e saber-fazer teatro-educação, dos procedimentos, da experimentaçáo com teatro, das anotaçóes e das reflexốes com o teatro em práticas educativas, neste presente caso, em um Galpão chamado Escola do Presídio, localizado no interior de Sáo Paulo.

Então, pergunto-me: em que direção para essa aventura eu devo prosseguir enquanto orientação para elucidar as minhas indagaçóes acerca do processo do fazer teatro como um processo que possibilite um conhecimento para a experiência educativa a partir de uma prática que envolva a criação, o fazer, o pensar e, portanto, contribuiçóes para o trabalho artístico-estético-pedagógica do professor-artista ${ }^{1}$ de teatro em práticas educativas tanto formais (escola) quanto não formais (presídios, ONGs, hospitais, associaçóes etc.)?

Aventuro-me, então, a narrar uma prática artístico-estéticopedagógica vivenciada com teatro tomando-a como área de conhecimento (emoção-razão-criação) e, portanto, um conhecimento poético (criação) que possibilite um campo de investigação-criação enquanto metáfora do navio do conhecimento, ou seja, um campo para uma ampla aprendizagem desse criar, fazer e pensar com o teatro em contextos educativos. Entáo, aventuro-me a pensar a Pedagogia do Teatro: teatro-educação como um campo de criação-investigação, pois, como salienta Carreira (2012), criação e investigação são elementos inseparáveis e complementares nesse fazer artístico com teatro.

Nessa perspectiva, o meu olhar para esse teatro-educaçáo centrase na aprendizagem com o fazer teatro a partir do próprio brincar com corpo, já que esse corpo compreendo como um território a ser 
explorado, transformado, habitado e ciente das suas sensações, emoçôes, valores, desejo, paixóes, sentimentos e, portanto, um corpo em metamorfose em que busco promover o autoconhecimento, a criaçáo, a cooperação, a emancipação e a humanização a partir de um processo de trabalho com teatro. Portanto, cabe-nos pensar que tal encaminhamento deva levar em conta que há um corpo social ${ }^{2}$ que compóe uma partitura e que é preciso seguir seus compassos, uma vez que "[...] ela procurará, mais vivamente, surpreender a razão interna em ação nos fenômenos sociais, em seguida proporá, em crescendo, abordar a delicada questão da experiência vivida, do senso comum que é a expressão desta, e da temática do sensível" (Maffesoli, 1998, p. 16).

Nesse sentido, possibilitar uma educação estética (fazer, criar e pensar) a partir do teatro é possibilitar também os fenômenos sociais (micro ao macro), que Maffesoli (1998) denomina sinergia da razão $e$ do sensivel, por contemplar o afeto, o emocional, o afetual, que, segundo ele, são da ordem da paixão e não estão mais separados, tanto do domínio da esfera pública quanto das categorias psicológicas explicáveis, mas que se tornam do ponto de vista metodológico, o aporte para possibilitar reflexóes epistemológicas capazes de explicar os múltiplos fenômenos sociais, muitas vezes incompreensíveis para nós e, portanto, possibilitar aquilo que ele chama de percepção global, já que:

É preciso compreender que racionalismo, em sua pretensão cientifica, é particularmente inapto para perceber, ainda mais apreender, o aspecto denso, imagético, simbólico, da experiência vivida. A abstraçáo não entra em jogo quando o que prevalece é o fervilhar de um novo nascimento. É preciso, imediatamente, mobilizar todas as capacidades que estáo em poder do intelecto humano, inclusive as da sensibilidade (Maffesoli, 1998, p. 31).

Nessa perspectiva, tomo os saberes e o saber-fazer em teatroeducação como possibilidades para ampliar a pratica pedagógica a partir de experimentaçóes tais como: a ação corporal/vocal (o autoconhecimento); os jogos: tradicionais e teatrais (o exercício de atuação); os jogos de improvisaçáo (prática teatral - discurso da cena); e, por fim, o processo de criaçáo-investigaçáo da cena teatral (comunicação entre palco-plateia), que possibilitam, a meu ver, uma ampla discussão para o processo de aprendizagem com teatro em contextos educativos sociais. 
Parto, entáo, para uma aventura do fazer teatro em que a emoção, a razão e a criação estão sempre juntas para me guiar como um campo de incertezas e certezas, sentimentos, dor, alegria, prazer e desprazer, objetividade, subjetividades, sonhos, mitos, crenças, valores e representaçóes em um processo cujo foco esteja, portanto, no processo amplo de aprendizagem com o teatro (ensinar-aprender e aprender-ensinar), mas uma aprendizagem que permita um conhecimento de $s i$, do outro e com o mundo. Nesse sentido, aventurei-me em uma prática teatral em que a emoção, a intuição e a imaginação pudessem guiar a minha prática artístico-estético-pedagógica em um processo de trabalho com o teatro e que, nesse processo, portanto, possibilitassem o autoconhecimento, a criatividade, a ética, a cooperaçáo, a socialidade (estar junto), a aprendizagem, a autonomia, a emancipação e a humanização, uma vez que o seu universo parte de:

[...] elementos extraídos do mundo sensível, outro mundo, fecundo em ambigüidades. [...] Ela nos ensina muito sobre nosso próprio universo, de um modo específico, que não passa pelo discurso pedagógico, mas por um contacto contínuo, por freqüentação que refina o nosso espírito (Coli, 1995, p. 111).

É nessa perspectiva que talvez há uma necessidade de ampliar o nosso olhar para uma prática teatral (neste caso, uma prática teatral pautada num criar, fazer e pensar para experiência educativa) enquanto um paradigma emergente ${ }^{3}$. Segundo Morin (2007), um paradigma emergente deve ser um conhecimento prudente para uma vida decente e, assim, um paradigma não apenas científico (paradigma de um conhecimento prudente), mas um paradigma social (paradigma de uma vida decente), uma vez que considera a ciência social como uma ciência subjectiva com o intuito de compreender os fenômenos sociais mediante suas açóes, pois, segundo ele, torna-se necessário utilizar:

[...] métodos de investigaçóes e mesmo critérios epistemológicos diferentes dos correntes nas ciências naturais; métodos qualitativos em vez de quantitativos, com vista à obtenção de um conhecimento intersubjectivo, descritivo e compreensivo, em vez de um conhecimento objectivo, explicativo e nomotético (Morin, 2007, p. 22).

Aventuro-me, assim, a tomar por base o conhecimento ainda denominado como não racional (emoções, sentimentos, paixões, intuição), ou seja, um conhecimento que é produzido, compartilhado 
no cotidiano, visto que, conforme Macedo, “[...] é na vida cotidiana que se desenvolve a sensibilidade, a percepção hermenêutica do trajeto histórico comum, a compreensáo dos processos identitários culturais, a enculturação do funcionamento mental, sem os quais, somos apenas componentes" (2000, p. 63). O trabalho aqui exposto por mim a partir de um relato etnográfico do fazer teatro em um terreno habitado pressupóe, conforme Macedo (2000), a existência de um mundo empírico disponível para ser observado, estudado e analisado.

Diante disso, tomo como premissa dessa aventura o teatro enquanto uma área de conhecimento aberto e sensível, por entender que, nas práticas educativas, devemos observar o que está vivo (nasce, cresce, desenvolve-se e fortalece-se) neste cotidiano (Galpão Escola do Presídio, como veremos a seguir) e o que, portanto, tem seu ritmo (desenho e esquema), surgindo, a partir daí, suas histórias de vida, suas tragédias, suas paixões, suas alegrias, suas tristezas, seus prazeres e desprazeres, suas angústias e seus sonhos presentes neste solo (presídio), já que não podemos “[...] negligenciar nada naquilo que nos cerca, neste mundo, no qual estamos e que é, ao mesmo tempo, sentimento e razão" (Maffesoli, 1998, p. 59).

Nessa perspectiva, a exposição de uma prática artístico-estéticopedagógica com teatro - a exposição será um recorte da pesquisa de doutorado - enquanto pesquisador participante (oficineiro) aqui apresentada, que teve o intuito de "[...] levantar compreensivamente o véu que cobre a área ou a vida das pessoas e dos grupos que alguém se propóe a estudar" (Macedo, 2000, p. 144), isto é, com detentos e, portanto, a produção de narrativas deles sobre o seu envolvimento com o brincar com teatro em práticas educativas.

\section{Uma Descriçáo Etnográfica de uma Prática com O Brincar com Teatro no Espaço Chamado Galpáo Escola do Presídio - ida e vinda: tempo, tempo, tempo...}

Aventura-se para buscar, num campo delimitado, a produção de conhecimento e, a partir daí, partir para procedimentos tais como: métodos, técnicas e análises como elementos para sistematizar esse conhecimento de cunho artístico, que, inserido nesse campo de investigação, permite ser apreendido numa pesquisa social, uma vez que esses elementos são resultados construídos nos processos de comunicação (diálogo entre o pesquisador e pessoas do seu campo) 
a partir da realidade social no trabalho de investigação, conforme salientaram Bauer e Gaskell (2008).

Assim, aventuro-me em um procedimento metodológico, a "pesquisa etnográfica”, que, conforme Angrosino, “[...] é a arte e a ciência de descrever um grupo humano - suas instituiçóes, seus comportamentos interpessoais, suas produçóes materiais e suas crenças", pois se ocupam basicamente com a "[...] vida do cotidiano rotineiro das pessoas investigadas" (2009, p. 30-31). Neste sentido, a observação (observação participante/oficineiro de teatro); a pesquisa em arquivo (documentos, fotos, diários, cartas, maquetes, vídeos, anotaçóes etc.) e a entrevista ${ }^{4}$, tomo-a como inspiração (metodo)lógica sensível para ser o ponto de partida que foi essa aventura e, a partir daí, possibilitar as vozes aos coautores (informantes: monitores culturais detentos) dessa investigação com o intuito de apreender as suas expressividades, falas e pensamentos (Bauer; Gaskel; 2008) para essa investigação com o teatro-educação no contexto presidiário.

É nessa perspectiva que faço um convite aos leitores com o intuito de permitir, por meio de uma etnografia centrada enquanto observador-participante e operando nesse terreno (Galpão Escola do Presídio), uma prática com teatro a fim de aflorar junto aos detentos uma razáo sensivel (interna) que, segundo Maffesoli, é "[...] atenciosas à paixão, à emoção, numa palavra, aos afetos de que estão impregnados os fenômenos humanos" (1998, p. 12) a partir do brincar com o teatro no espaço carcerário.

A imagem do Galpão Escola do Presídio aqui narrada parte da inserçáo no campo e o envolvimento para produzir a escrita a partir de um olhar aberto e sensível. $\mathrm{O}$ meu trabalho de campo começava a partir das 3 h30 da madrugada, isto é, acordava, tomava um banho e um rápido café para fazer uma caminhada de vinte e cinco minutos até o terminal rodoviário, sair às 5 h e viajar durante uma hora e meia para chegar à outra cidade e, por volta das $6 \mathrm{~h} 40$, entrar em um outro ônibus para estar às $8 \mathrm{~h}$ no portão do presídio. Entrava às $8 \mathrm{~h}$ da manhá e saía apenas às 16h; a partir daí, fazia todo o percurso de volta para casa, chegando por volta das $20 \mathrm{~h}$.

Durante um ano e nove meses (de março de 2008 a dezembro de 2009), viajei quatrocentos e sessenta quilômetros (ida e volta), duas vezes por semana, para estar no trabalho de campo como pesquisador-participante 5 para observar, estudar e analisar. Tarefa ár- 
dua e necessária, pois concordo com Laplantine ao afirmar que, ao estarmos no campo, devemos ser capazes de viver, no seu íntimo, a tendência principal da cultura que se está estudando (2004, p. 22); neste caso, em um contexto presidiário, junto com um grupo de Monitores Culturais Detentos - neste presente caso, monitores selecionados pela diretoria do presídio para atuar como professores no Galpão Escola em ensino de alfabetização, fundamental e médio de jovens e adultos também presos.

Ao passar pelo primeiro portão do presídio e fazer uma caminhada de cinco minutos, chegava ao presídio $\mathrm{II}^{6}$. Às $8 \mathrm{~h} 30$, adentrava no pavilhão do Galpão Escola Presídio, localizado no interior de São Paulo. Respiraçáo descontrolada. Grades se abrindo e se fechando. Um som estrondeante de um cadeado se fechando. Estou no Galpão Escola do Presídio, assim denominado pelos agentes da penitenciária. Entro no Galpáo e, ao olhar a vida, deparo-me com o homem em situação de privação de liberdade. Para tanto, ao olhar essas vidas, deparo-me com um cenário de alegrias, tristezas, angústias, sonhos, frustraçóes, desejos, prazeres, desprazeres, paixōes e emoções.

Olhar tudo isso e querer apreender, mas o quê e como? Viver tudo isso é mesmo uma desorganização, como já dizia Clarice Lispector, pois saímos do nosso eixo para sentir aquilo que nunca sentimos ou até mesmo o que não vivemos. Assim, decido buscar buscar aquilo que desejamos e que, de certa forma, encontrarei, mas talvez fragmentado, solto, espalhado, um pouco ali, um pouco aqui - para tentar sistematizar e produzir um conhecimento por meio da inspiração com o teatro. Sim, pois é essa inspiração (Macedo, 2000) que me motivou a aventurar-me nesse espaço e, a partir daí, poder desorganizar para depois organizar e, portanto, sistematizar uma prática com o teatro no presídio.

Nesse sentido, foi possível estar-junto com os detentos e, assim, produzir as suas narrativas, já que eles participaram da oficina intitulada por mim O Brincar com Teatro, tomando como procedimentos para essa empreitada tanto jogos tradicionais (brincadeiras de rodas, cantigas) quanto jogos teatrais (aprender jogar/atuar cenicamente com o outro), uma vez que ambas possibilitavam uma aprendizagem focada no autoconhecimento de si e do outro, que foram essenciais para refletir enquanto urgência a humanização deles mediante ao espaço em que se encontravam, isto é, o espaço carcerário. 
Nessa perspectiva, a oficina $O$ Brincar com Teatro não visava, nesse primeiro momento, fazer uma montagem teatral, mas sim possibilitar o resgate da sua identidade, história e memória e, além disso, aproximar-me dos detentos para apreender como o teatro poderia possibilitar outro olhar para o ambiente carcerário. Assim, possibilitei exercitar a prática teatral nesse ambiente na possibilidade de ressignificar o cotidiano carcerário e, assim, possibilitar uma discussão acerca dos nossos desejos, angústias, tristezas e alegrias a partir do brincar com o teatro enquanto prática artístico-estético-pedagógica. Foi nesse cotidiano que pude aprender "[...] pistas, indícios, evidências, conselhos e alertas que, de uma forma ou de outra, ajudam na decifração dos enigmas da vida cotidiana" (Oliveira; Sgarbi, p. 18, 2008), neste caso, com pessoas privadas de sua liberdade.

Aprender a escutar (histórias de vida, fracassos, alegrias, tristezas, revoltas) foi a minha maior aprendizagem e, de certa forma, também o exercício de educador, oficineiro, artista, pois fui percebendo, a partir daí, a maturidade como pesquisador e a importância de exercitar a sensibilidade para possibilitar uma prática com teatro e, por meio dela, promover uma ampla aprendizagem que se contempla com a cooperação, a criação, a investigação e a humanização dos envolvidos. Eu, particularmente, já não era mais o mesmo naquele momento...

Ao entrar no presídio II, dirigia-me para a área de administração, onde funciona toda a parte administrativa do presídio. Assim, cumprimentava todos os funcionários e tomava um café com pão e fatias de queijo com eles. Esse ritual que sempre eu fazia possibilitava-me aproximar-me deles e, de certa forma, ajudar a manter-me mais próximo e estabelecer um vínculo harmonioso, pois o estar no trabalho de campo - ter acesso - requer certa confiança, que, conforme Macedo, pode "[...] fundamentar disponibilidade das pessoas para informar, deixar-se observar, participar ativamente da pesquisa, co-construir o estudo como um todo" (2004, p. 148). Nesta perspectiva, obtive o meu acesso ao espaço carcerário com louvor, uma vez que foi possível acompanhar os monitores culturais detentos que lecionavam desde a alfabetização até o ensino fundamental e médio para outros detentos.

Foi após muitos desses cafés que comecei a entrosar-me com os agentes da penitenciária com o intuito de obter a confiança, pois, como diz Macedo, há de se saber transitar enquanto investigador interessado em ouvir para que as portas náo se tranquem definitiva- 


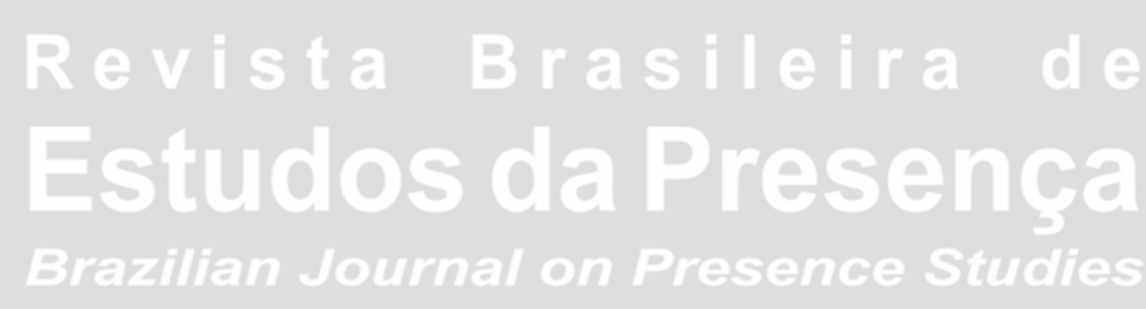

mente (2000, s.p.). Portanto, ouvia as histórias de vida dos agentes, as alegrias, tristezas, sonhos e frustraçôes. Em seguida, ia para o Centro de Educação e Trabalho da Unidade Prisional para que fosse autorizada a minha entrada de fato no interior do presídio e lá encontrar o terreno delimitado (Galpáo Escola do Presídio) e os informantes (Monitores Culturais Detentos).

Mas, para estar lá, era preciso que um agente penitenciário me acompanhasse até um segundo portáo, imenso, com um enorme cadeado, para ser revistado por outro agente de cima para baixo e somente depois chegar ao Galpão. Mais uma vez, abria-se outro portáo e outra grade de ferro, de cor amarela, para de fato adentrar no espaço chamado Galpão Escola do Presídio, conforme mostra a imagem abaixo:

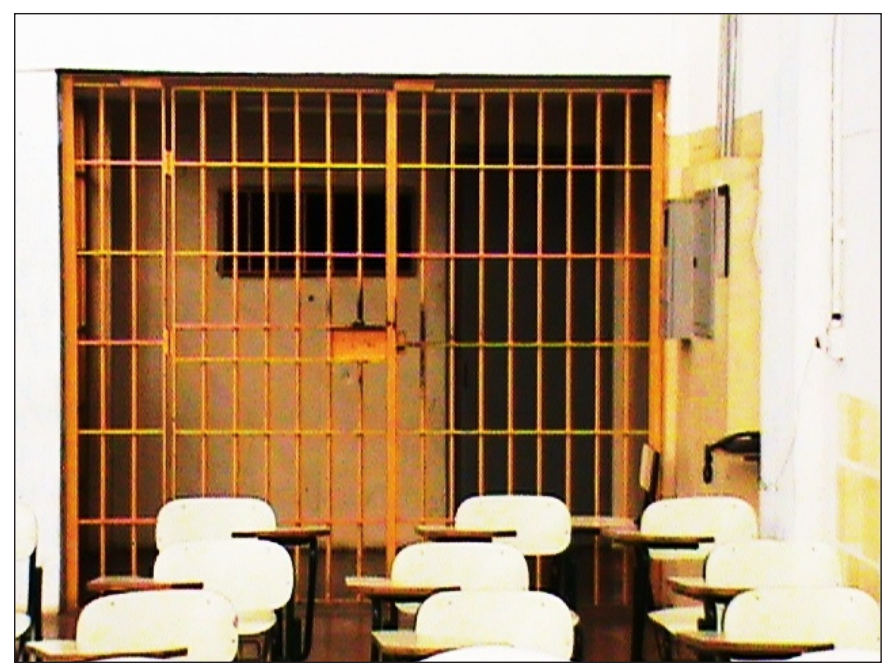

Imagem 1 -Entrada para o Galpão Escola do Presídio, 2009. Ensaio Fotoetnográfico. Foto: Micael Côrtes.

Essas grades amarelas sinalizavam a passagem para o Galpão, que se denominava como um espaço de aprendizagem dos detentos, isto é, a escola do presidio que foi idealizada pela Secretaria da Administração Penitenciária (SAP). Além desse Galpão, existem mais três nessa Unidade Prisional, cada um com cerca de quatrocentos metros quadrados. Nos outros galpóes, como, por exemplo, ao lado da escola, funciona a cozinha da unidade, e os dois remanescentes servem para a implantação de empresas que darão trabalho laborterápicos aos detentos. Por restrição, eu só pude ter acesso ao Galpão da Escola do Presídio.

Pode-se dizer que o Galpão Escola do Presídio, onde permaneci durante um ano e nove meses - em um primeiro momento, contratado pela Fundação de Amparo ao Preso (FUNAP) em 2008 e, 
posteriormente, em 2009, como pesquisador autorizado pelo diretor do presídio -, mede quatrocentos metros quadrados, ou seja, dez metros de largura com quarenta de comprimento. Naquele momento, comportava uma biblioteca de aproximadamente vinte metros quadrados com cerca de quatro mil volumes; três salas de aula, com vinte e cinco metros quadrados cada; uma sala para os monitores, com um acervo de livros didáticos e paradidáticos de aproximadamente mil e quinhentos itens/unidades, incluindo, nesse número, uma pequena porcentagem de revistas especializadas em ciências e história; um refeitório e dois banheiros.

Especificamente, o desenho representado abaixo retrata a sala dos monitores culturais detentos para o planejamento das suas aulas e o aguardo dos demais detentos, além das reuniôes com o diretor responsável pela área de trabalho e educaçáo. Na sala, há um acervo de livros para uso didático que se divide em língua portuguesa, língua inglesa, ciências, matemática, história, geografia, química, física e pouco material relacionado à área de arte. Contam ainda com o apoio de um aparelho de DVD, uma televisão de vinte polegadas, um videocassete e um aparelho de som - muito utilizado nos dias de aulas pelos monitores - e, por fim, uma saída para um pátio descoberto de cinquenta metros quadrados no qual era possível a saída (conforme o desenho abaixo) dos monitores (somente eles!) e, neste sentido, a possibilidade de verem o céu enquadrado - momento este que, muitas vezes, deixava-me agoniado.

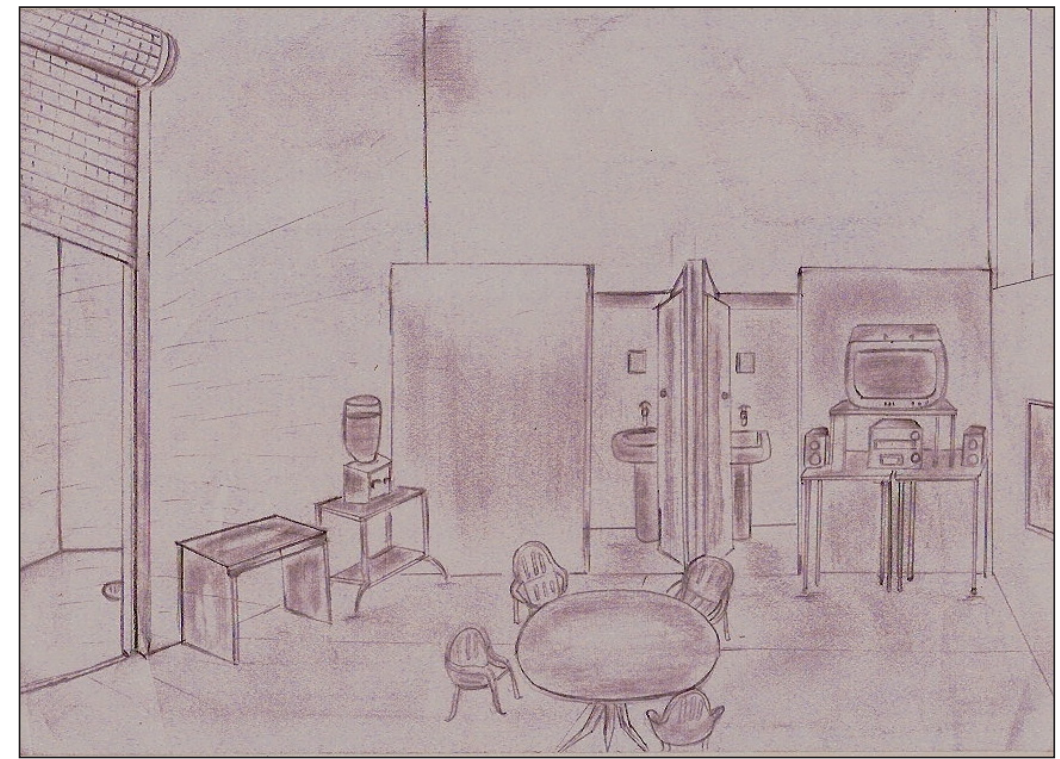

Imagem 2 - Sala dos Monitores para os planejamentos das atividades, 2008. Desenho do Monitor R.

Micael Côrtes - Portas EntreAbertas: um relato etnográfico a partir de um fazer teatro com pessoas privadas de liberdade - para além do espetáculo... Rev. Bras. Estud. Presença, Porto Alegre, v. 4, n. 2, p. 351-376, maio/ago. 2014. Disponível em: <http://www.seer.ufrgs.br/presenca> 
Nessa mesma sala, eu também permanecia junto a eles por oito horas (das $8 \mathrm{~h}$ às $16 \mathrm{~h}$ ) para desenvolver o projeto intitulado Projeto Processos Educativos Através do Teatro, financiado pela FUNAP no ano de 2008, sob a responsabilidade de Jorge Spínola. O objetivo do projeto era a inserçáo do teatro nas escolas dos presídios do estado de Sáo Paulo. Nesse primeiro encontro, foi-me apresentado tanto o Galpão Escola quanto os nove monitores culturais detentos contratados pela FUNAP, sendo: seis que exerciam, até naquele momento, a função de professor; um que trabalhava na biblioteca; e dois que eram responsáveis pela faxina do espaço denominado escola. A partir daí, foi-me possível explicar os objetivos do projeto e a importância dele para a sua realização no presídio.

Os monitores mostraram-se curiosos com relação à possibilidade de fazer teatro no espaço carcerário e o comprometimento em participar tanto da oficina intitulada $O$ Brincar com Teatro ${ }^{7}$ quanto da divulgaçáo do projeto aos frequentadores da escola e aos que náo a frequentavam.

Nessa perspectiva, a oficina pautava-se na introdução dos jogos tradicionais (brincadeiras e cantigas), que foram desenvolvidos como um exercício de pré-aquecimento (corpo/voz), levando em conta o prazer e a satisfação do brincar com o seu corpo. Essa experimentação pode ser apreendida na narrativa de um dos monitores quando narra que o ato de brincar com os jogos possibilita "[...] um remédio para afastar o tédio, as náuseas do complexo momento que me encontro... Quero dizer que foi o começo de uma experiência muito legal, entretanto, me senti um pouco estranho e ao mesmo tempo com a mente solta. Contudo consegui sair do ambiente a qual me encontro" (Diário do Monitor M., 2008, s.p.). Portanto, o prazer de jogar permitia o favorecimento da ludicidade e, assim, a possibilidade de amenizar o sofrimento por estar privado de sua liberdade.

Esses encontros, que duravam uma hora e meia, tinham o intuito de investigar o repertório que os monitores tinham ou não dos jogos tradicionais e, assim, possibilitar o brincar e a reflexão sobre essa prática no espaço carcerário, como podemos apreender na imagem abaixo: 


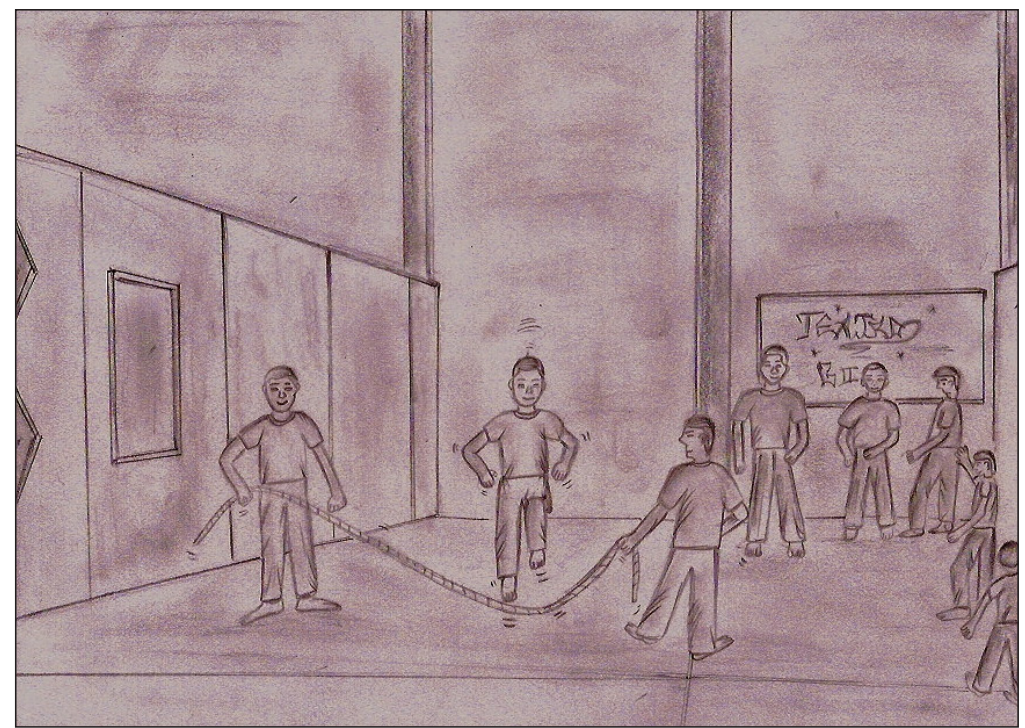

Imagem 4 - Oficina d'O Brincar com Teatro: pular corda, 2008. Desenho do Monitor RSG.

Os jogos tradicionais foram desenvolvidos em várias sessôes, sendo distribuídos entre jogos e cantigas, porém experimentando junto a eles outras regras desse jogar, como, por exemplo: escravo de Jó, pai Francisco, cabra-cega, amarelinha, Terezinha de Jesus, boca de forno, pula corda, durinho, arlequim, a canoa virou, queimada etc., que proporcionavam investigar as regras preestabelecidas e o prazer do jogar e modificar as regras e, diante disso, o despertar do seu próprio corpo, isto é, a alegria, a satisfaçáo, o tocar, o respeitar o outro e o estar-junto nesse espaço carcerário:

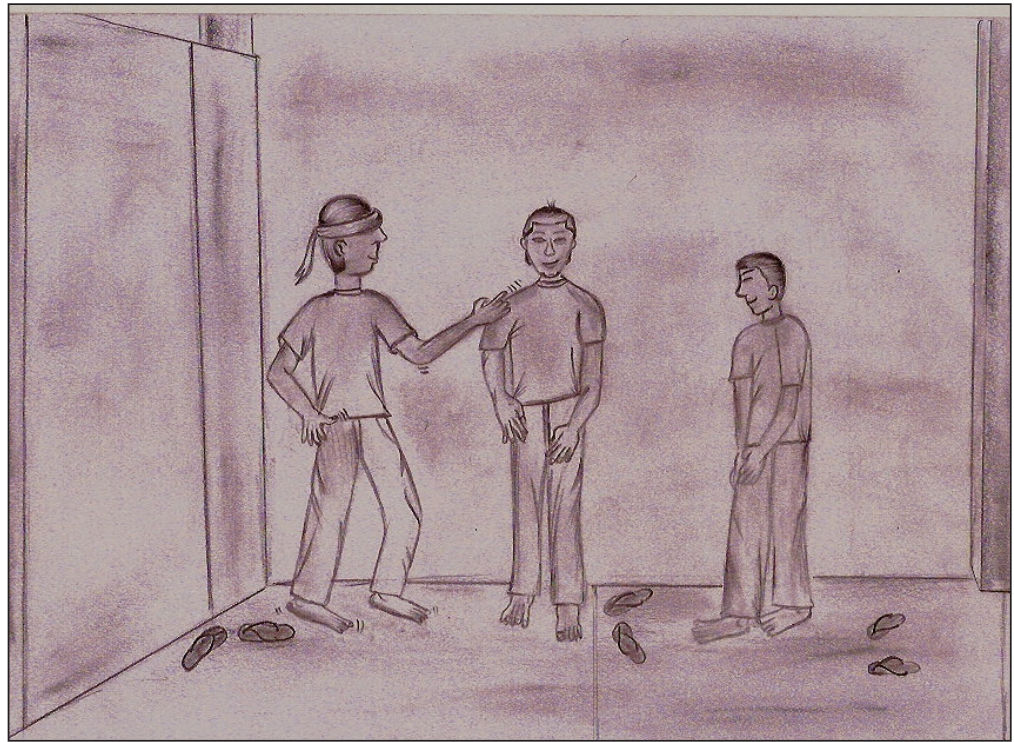

Imagem 5 - Oficina d'O Brincar com Teatro: cabra-cega, 2008. Desenho do Monitor RSG.

Micael Côrtes - Portas EntreAbertas: um relato etnográfico a partir de um fazer teatro com pessoas privadas de liberdade - para além do espetáculo... Rev. Bras. Estud. Presença, Porto Alegre, v. 4, n. 2, p. 351-376, maio/ago. 2014. Disponível em: <http://www.seer.ufrgs.br/presenca> 
$\mathrm{O}$ ato de possibilitar os jogos dentro de um sistema carcerário favoreceu para eles uma reflexão acerca do seu corpo aprisionado e, portanto, a discussão de "[...] uma grande mutilação do eu" (Goffman, 1987), isto é, o desculturamento, o despir de si, a padronização, a degradação, a humilhação, a profanação e os rituais de admissão ${ }^{8}$, que, de certa forma, podemos apreender no desenho abaixo, Resgate Cerebral, criado por um dos monitores:

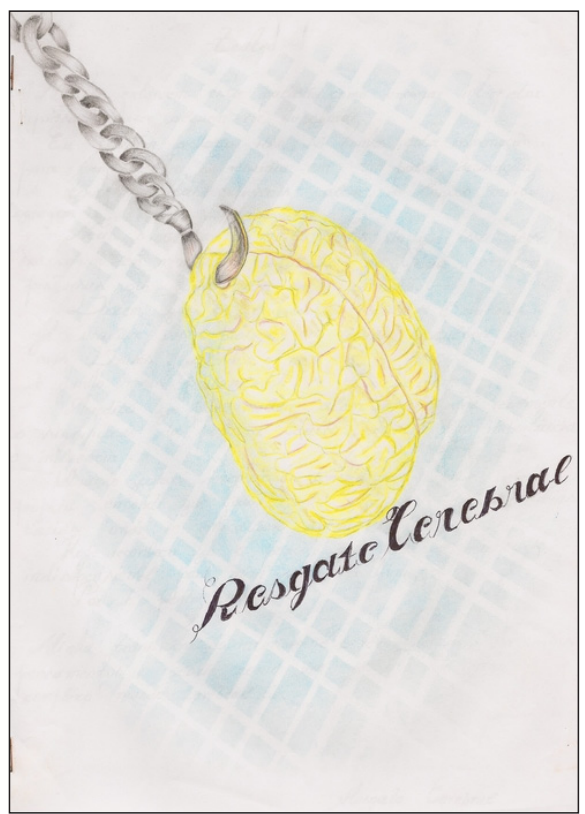

Imagem 3 - Desenho intitulado Resgate Cerebral após a sua participação, 2008. Desenho do Monitor R.

Ver essa imagem possibilitou-me o exercício do olhar conforme Laplantine, para quem (2004) a palavra ver significa sempre o que está na frente, pois, conforme ele, a palavra designa um contato imediato com o mundo que náo necessita nenhuma preparaçáo, nem treino, nenhuma escolaridade, já que ver é receber imagens e, portanto, “[...] não se limita a uma percepção exclusivamente visual. Ela mobiliza a totalidade da inteligência, da sensibilidade e até da sensualidade do pesquisador" (Laplantine, 2004, p. 20). Nesse sentido, olhar essa imagem levou-me a refletir sobre o fato de que o teatro possibilita contribuir para o resgate de si como pessoa e, portanto, o processo de humanização, como podemos perceber na escrita do Monitor R.:

[...] quando comecei a descobrir os benefícios que esta arte propicia entendi que tudo aquilo que pensava eram ideias vazias onde se enforcavam apenas nos espetáculos. Hoje reconheço que o pouco que aprendi tornou-se indispensável para mim como ser humano. Por quê assim: minha transformação interior é reconhecida, em meus pensamentos, 
ocorre como um resgate no meu complexo mundo cerebral (Diário do Monitor R., 2008, s.p.).

Assim, a experimentação do brincar com o teatro no presídio possibilitou aos monitores detentos uma ampla aprendizagem enquanto autoconhecimento, já que:

[...] o teatro desenvolveu a capacidade de percepção raciocínio, amplitude dos espaços líricos e imaginários, criando obstáculos há serem vencidos de maneira coletiva e ao mesmo tempo individual. Desenvolveu ainda, situaçóes e ocasiōes imaginárias utilizando como base o próprio meio em que está. Estimular o corpo físico a lidar com sua limitaçáo, exercitando membros que se mantém acomodados a uma rotina repetitiva, onde não são exercitados de forma correta na prática das funçóes habituais do corpo (Diário do Monitor R., 2008, s.p.).

Essa primeira etapa tinha o intuito de discutir as possibilidades de experimentar a prática teatral para além do espetáculo, visto que a ideia que eles tinham, num primeiro momento, era de que iríamos montar uma peça de teatro - optei por náo começar por aí, mas privilegiar o encontro, isto é, o processo de trabalho (fazer, criar, pensar) no que se refere ao autoconhecimento de si e do outro.

Nesse sentido, a experimentação d'O Brincar com Teatro a partir dos jogos possibilitou para eles a reflexáo sobre seu corpo no espaço carcerário, como narra outro monitor:

[...] no princípio tive a impressão que era um singelo labor, contudo o teatro e sua relação de - palco e plateia - no decorrer do processo contemplei a sensação de voltar a dominar o meu eu e sincrônico transitar com os pensamentos do presente para o futuro e construir e reconstruir os meus sonhos... [...] na psicografia dantes de iniciar o processo do fortalecimento do eu tratarei de lembrar. Parcialmente com o empobrecimento e desistente dos sonhos me encontrava inapto de atravessar fronteiras, obstáculos e sair do presente e percorrer o imaginário do futuro e da perspectiva dos ideais... (Diário do Monitor M., 2008, s.p.).

Portanto, ao possibilitar o ato lúdico por meio do teatro, tal experiência fez com que os detentos fossem ao encontro de si e do outro e, a partir daí, resgatar suas histórias, tragédias, alegrias, desejos, angústias e sonhos como elementos essenciais para o fortalecimento do seu eu.

O que pude observar nesses encontros foi que a oficina de teatro estava contribuindo para ressignificar e reencantar o próprio espaço 
carcerário, já que tal ressignificação estava possibilitando compreenderem o seu sofrimento por estarem privados de sua liberdade e, assim, expressar o que um deles narrou: "Eu não sou preso. Eu estou preso" (Diário do Monitor E., 2008, s.p.). Essa frase revela o quanto o teatro como processo artístico-estético-pedagógico, possibilitou o resgate cerebral de ambos e o exercício diário para que não se tornassem um número, um preso, mas sim uma pessoa no cotidiano carcerário - os detentos não são chamados pelos seus nomes, e sim pelo número. Por outro lado, pude também me angustiar mediante aos percalços para desenvolver a prática teatral no presídio, pois, quando não eram a suspensão da oficina por parte da administração do presídio e, portanto, a não permissão para a minha entrada no Galpão Escola, em outros momentos, eram os relatos de angústias e sofrimento deles quando saíam do Galpão Escola e retornavam para os respectivos raios (celas). Nesses dias, o que me restava era apenas possibilitar a escuta sensível.

Talvez a oficina não tenha sido contemplada como um todo devido aos problemas do cotidiano (nesse presente caso, as revistas nas celas feitas de surpresa pelos agentes da penitenciária), que, às vezes, impediam que eles fossem para o Galpão Escola, como podemos apreender na escrita de um monitor: “[...] o trabalho de 'oficina' feito pelo professor é um trabalho interessante e até promissor, embora, os percalços cotidianos não nos permitam desfrutar na íntegra os benefícios do mesmo" (Diário do Monitor C., 2008, s.p.). Mas, por outro lado, possibilitar aos detentos o Brincar com Teatro revelou a importância dessa prática para a experiência educativa, particularmente o estar-junto e, assim, promover a reflexáo que uma prática desse porte (teatro) em práticas educativas (presídio) pode possibilitar para uma formação ampla da pessoa (biopsicosociocultural) a partir de uma prática artístico-estético-pedagógica em que se possa favorecer uma “[...] sinergia da razão e do sensível” (Maffesoli, 1998, p. 53), já que o afeto, o emocional e o afetual contribuiráo para uma ampla aprendizagem dos envolvidos com o teatro.

Para tanto, O Brincar com Teatro pautava, para mim, a possibilidade de promover a experimentação (jogos: tradicionais e teatrais), o pensar (atitudes, sensações, regras) e o apreciar (criação das cenas improvisadas) com a prática dos jogos tradicionais e teatrais. Esse desejo pode ser contemplado na narrativa de um dos monitores quando diz que: 
[...] esse projeto é uma esperança para o reeducando de aprimoramento, só posso agradecer pela oportunidade de participação e espero que o projeto consiga atingir a muitos mais reeducandos. Sem dúvida essa experiência teatral de muito me valeu, achei importante porque pode proporcionar um maior entrosamento entre os monitores e, além disso, a oportunidade de adquirir novos conhecimentos nesse lugar insólito é até uma 'sorte'. Um fato que dificilmente ocorre aqui. Basta saber que nos quatro anos em que estive preso nada, nada vi de novo, inovador, benefício, útil ao preso. [...] Foram 5 meses, que sinceramente, pude dialogar, expor, intercambiar experiência de vida, de uma maneira mais 'informal', mais autentica, mais sincera. Para mim, foi muito benéfica a experiência de teatro, acredito que para os demais presos também seria, mas aqui, atender a muitos presos é mesmo uma dificuldade (Diário do Monitor E., 2008, s.p.).

Nesta perspectiva, elaborei uma proposta de trabalho que pudesse continuar essa aventura, criando, a partir daí, os seguintes procedimentos, a saber: 1) Grupo de Estudos; 2) Laboratório do Brincar com Teatro; e 3) Pesquisa Cênica?.

O Grupo de Estudos tinha como objetivo a prática da leitura em grupo, que envolvia os estudos do teatro e educação - saberes e saber-fazer -, uma vez que eles solicitaram um aprofundamento nessa área. Tal solicitação justifica-se pela experiência deles na oficina e, portanto, as contribuiçóes que o teatro possibilita para o ato educativo, já que lecionavam ambas as áreas na escola do presídio. Já o Laboratório Teatral possibilitava trabalhar a ação corporal/vocal a partir dos jogos tradicionais (brincadeiras e cantigas - escravo de Jó, pai Francisco, cabra-cega, amarelinha, Terezinha de Jesus, boca de forno, pula corda, durinho, arlequim, a canoa virou, queimada etc.) e dos jogos teatrais (estrutura dramática: onde? quem? o quê? - foco; fiscalização e avaliação) para uma prática de jogar com o outro e, em seguida, partir para os jogos de improvisaçáo - discurso da cena - e, assim, possibilitar um experimento a partir da criação-investigaçáo (nesse caso, a pesquisa cênica, como eu denominava) para a realização da composição cênica como o exercício do fazer teatral.

Para esses encontros, tomava como procedimento o trabalho com os jogos tradicionais e os jogos teatrais num primeiro momento e, em seguida, os jogos de improvisaçáo a partir de temas relacionados ao cotidiano dos detentos no presídio, como, por exemplo, as relações entre eles, os agentes e a instituição carcerária. Pode-se 
dizer que tal prática favorecia o trabalho para eles no que tange aos aspectos afetivos (emoçóes, sentimentos, motivaçóes, valores), cognitivos (conhecimento, percepção, reflexão) e psicomotores (açóes de comportamentos e atitudes), já que o ato de brincar com o teatro possibilitava pensar, criar e expressar as suas alegrias, tragédias e projetos de vida após cumprir as suas penas. Devo frisar que todo esse processo privilegiava o artístico-estético-pedagógico enquanto criação-investigação a partir do teatro.

O trabalho foi o realizado durante os anos de 2008 e 2009. Sempre havia atritos entre os agentes e os técnicos (educadores) responsáveis pelo Galpão Escola, principalmente quando era dia de revista geral por parte dos agentes nas celas (nesse dia, os detentos eram impedidos de ir ao Galpáo Escola) ou quando os detentos tinham que sair da sala de aula para participar da oficina. Foi necessário paciência da minha parte, bem como conquistar, aos poucos, os agentes da penitenciária, já que, a princípio, o teatro não era ainda bem visto por alguns (como pude observar): um comentário de um dos agentes que questionava o porquê desses criminosos terem aulas de teatro. Provocamos, assim, questionamentos, indagaçóes, críticas e até atritos para a manutenção desse projeto no Galpáo Escola do Presídio. Mas possibilitamos também uma mudança de valores, pois uma atividade artística desse porte exigia, naquele momento, a movimentação e circulação no espaço habitado. Tenho aí uma hipótese para esses questionamentos sobre o teatro no presídio: a ameaça ao mecanismo disciplinar (Foucault, 2008), uma vez que entendemos que essa atividade requer que as divisóes restritas do espaço - nesse caso, presídio - sejam abertas para a livre circulação dos detentos e, assim, a perda do controle sobre eles - questáo essa que se pode apreender também com os alunos no contexto escolar.

Vale ressaltar que o teatro, nas práticas educativas, (escolas, presídios, ONGs, comunidades locais, igrejas e outros) é concebido ainda (por educadores, pedagogos, professores, gestores, governo) apenas como uma montagem de peça feita às pressas ou, ainda, um produto (nesse caso, náo estou me referindo à velha dicotomia processo $X$ produto, uma vez que o produto é um resultado de um processo de criação estética, porém somente o produto pelo produto perde a sua dimensão artístico-estético-pedagógica e, portanto, uma aprendizagem ampla na formação da pessoa) e, por conseguinte, sem 
muita preocupaçáo com o seu processo do fazer teatro - processo este que envolve o fazer, pensar e criar. Neste sentido, possibilitar uma aprendizagem a partir dos saberes e um saber-fazer no campo do teatro-educação (práticas educativas formais e não formais) não consiste em proporcionar uma formação de atores, dramaturgos, cenógrafos, encenadores, sonoplastas, iluminadores dessa área teatral, mas possibilitar, na medida do possível, a experiência a partir desse conhecimento (teatro), com o intuito de possibilitar outra dimensáo na experiência educativa, particularmente, na formação ampla da pessoa.

Revivi situações passadas, criando um ambiente de confraternização junto ao próximo, ultrapassando barreiras. Para mim, os jogos desenvolveu em mim habilidades psicomotoras, exercitando para melhor dicção construindo melhores maneiras de expressão corporal ajudando desinibir o interior para uma melhor comunicação. Até que ponto tais atitudes e gestos solidárias estarão voltados para estes aqui esquecidos. Que existe um lugar amplo dentro da imaginação, que por meio das imagens, expressóes, interpretaçóes torna-se possível alcançar os objetivos. Muito obrigado! (Diário do Monitor R., 2008, s.p.).

Assim, teatro, nesse primeiro momento, provocou nos monitores a curiosidade sobre a ideia desses saberes e saber-fazer teatro, pois a arte, para alguns deles, era concebida apenas como um espetáculo (produto final), ou seja, náo havia muita preocupação com seu processo de trabalho, visto que o fazer teatral nas práticas educativas não consiste no que já foi explicitado acima, em uma formação profissional na área teatral, mas sim em possibilitar uma aprendizagem do fazer, criar e pensar essa experimentação com o teatro.

Nesse caso, julgo procedente a proposta de Benjamin, que vê o teatro enquanto possibilidade de despertar, no educador/educando, a verdadeira essência da educação e, portanto, a prática da observação a partir da busca da 'ação gestual' trabalhada e, assim, "[...] a grande pausa criativa no trabalho de educação" (Benjamin, 1988, p. 88), que, a meu ver, é possível contemplar por meio de um processo de experimentaçóes (fazer, criar e pensar), envolvendo os jogos tradicionais e teatrais (jogar/atuar); os jogos de improvisação (prática teatral/ discurso da cena); e a encenação ${ }^{10}$ (comunicação entre palco-plateia/a cena teatral), desta forma, possibilitando uma aprendizagem que possa abarcar elementos, como, por exemplo, o autoconhecimento, 
o trabalho coletivo, a responsabilidade, o comprometimento, a cooperação, a ética e a criação artística (teatro) como contribuição para a experiência educativa. Para este relato, foi feito um recorte para essa exposição, ou seja, a experimentação com os jogos realizada na oficina d'O Brincar com Teatro já explicitada.

Por esse motivo, foi desenvolvida, junto aos monitores, a noção de teatro-educação. Minha opção por essa terminologia opóe-se ao ensino de teatro tradicional, que propóe colocar somente o texto nas máos dos participantes para que eles decorem as falas e as marcaçóes, privilegiando o produto, isto é, o espetáculo teatral para um evento programado de festividades, como, por exemplo, as festividades comemorativas das instituiçóes, sem se preocupar com o processo de trabalho. O objetivo dessa oficina foi possibilitar uma contribuição para a formaçáo biopsicosociocultural dos monitores detentos, já que tal experimentação com teatro possibilitou o fortalecimento do seu eu e um tornar-se mais humano, como podemos apreender na escrita abaixo, do Monitor R.:

Estou sendo muito sincero não poderia deixar de mencionar o quanto o teatro e toda sua didática psicológica me ajudaram e me influenciam no meio em que estou, e no trabalho que exerço, durante este momento difícil da minha vida. Estar trabalhando e exercendo a função de educador me possibilita apreender mais, o teatro aparece como um complemento fortalecedor importantíssimo para melhorarme como ser humano. Refletir no passado e analisar como minha mente se modificou, tornou-se uma terapia posso reconhecer o quanto me fortaleci e me fortaleço, sinto-me preparado para novamente incluir-me na sociedade, mas isso não depende de mim. Tenha certeza que meus valores se reforçaram, minha sensibilidade aumentou, meu caráter se fortaleceu. Conseguirei com estes conhecimentos iniciar um pensamento de autocontrole sobre minhas neuroses, saber lidar com as vontades e prazeres. Lidar com as neuroses, como isso é constante em todo momento principalmente aqui, poder descarregar este sentimento por meios de açóes descobertas durante este projeto, usá-las com mais intensidade foi um aprendizado muito benéfico (Diário do Monitor R., 2008, s.p.).

Pode-se dizer que a intenção dessa oficina foi favorecer a promoçáo da saúde, da criatividade, da escuta, das histórias de vida, do pensar, da vivência do lúdico, da afetividade e da diversidade de relaçóes vivenciadas, com o intuito de contribuir para a elaboração de projetos de vida mediante suas escolhas. 
Portanto, o meu olhar para o campo da Pedagogia do Teatro pautava-se a partir dos saberes (concepções, métodos, finalidades) e do saber-fazer (processos de criação-investigação) teatro em práticas educativas. Esse saber-fazer na oficina de teatro privilegiava o trabalho com o corpo para o processo de criação-investigação (artísticoestético-pedagógico) a partir dos jogos tradicionais e teatrais como possibilidade para o movimentar, o criar, o pensar e o representar/ atuar. Para tanto, foi necessário que a instituiçáo (presídio) pudesse compreender que tal processo náo resultaria necessariamente em um produto, mas sim no processo que essa linguagem poderia provocar como experiência para esse grupo. Desta forma, a orientação para essa prática foi um convite feito aos detentos, incitando-os a buscarem outro olhar para esse trabalho e enfatizando não à formação de artista do teatro, mas um processo que contemplasse a experiência do fazer artístico e, a partir daí, uma prática que favorecesse a formação ampla da pessoa, nesse caso, deles próprios.

Iniciamos essa prática por meio de exercícios investigativos que favorecessem uma aproximação do grupo pautados nos jogos (jogos tradicionais) e, depois, nos jogos teatrais, ambos como procedimentos ${ }^{11}$. Essa prática investigativa possibilitou os participantes a despertar a curiosidade e, diante disso, a necessidade de estabelecer um comprometimento para a construção desse processo que, no decorrer do tempo, foi exigindo deles s a exposição das suas histórias de vida, tragédias, alegrias, angústias e sonhos por meio de uma (etno) biografia ${ }^{12}$ narrada por eles a cada encontro que fazíamos.

Esses encontros me fizeram pensar em pistas para um amplo processo de ensino-aprendizagem com teatro em práticas educativas, já que pude apreender, na narrativa abaixo, o quanto essa experiência contribui para as descobertas de si, as percepções e as transformaçóes como pessoa:

[...] sobre o teatro muitos entendem esta palavra como encenar interpretar expressar, fazer alguém rir ou chorar. Eu também achava isso! Só tinha esta informação e para mim teatro se resumia em um palco, decoração de textos muitas expressóes além de lógico muita coragem. Desde o mês de junho meus pensamentos se modificaram. Acredito que para melhor além de conhecer realmente o significado da palavra teatro, descobri sua importância e influência. Quando comecei descobrir os benefícios que esta arte propicia entendi que tudo aquilo que pensava eram idéias 
vazias onde se enforcavam apenas nos espetáculos. Hoje reconheço que o pouco que aprendi tornou-se indispensável para mim como ser humano. Porquê assim: Minha transformação interior é reconhecida, em meus pensamentos, ocorre como um resgate no meu complexo mundo cerebral. Em que sentido isso acontece, consigo me expressar melhor entender, interpretar lidar melhor com a insegurança com as diferenças e indiferenças. Meus pontos de vista sobre determinados assuntos e pessoas tornaram-se mais próprios, consigo me convencer sobre minhas opiniôes; náo me questiono e se acontece analiso melhor e repenso sobre elas. Foi um novo campo de visão e pensamentos que surgiu em mim, tenho certeza que a partir do momento que estes conhecimentos afloraram tornei-me mais humanos em vários sentidos. Porquê assim: Minha transformação interior é reconhecida, em meus pensamentos, ocorre como um resgate no meu complexo mundo cerebral (Diário do Monitor R., 2008, s.p.).

Diante disso, percebo que a nossa educaçáo, num processo de ensino-aprendizagem, privilegia ainda a cultura da escrita, deixando de lado a importância das histórias de vida, das emoçóes, da imaginação, da intuição, da criação, das paixóes, dos fracassos, dos sonhos que permeia a vida humana - itens importantes para se pensar nas práticas educativas com as artes (educação estética) e, a partir daí, $\mathrm{o}$ ato educativo.

O que pude enxergar naquele espaço carcerário era a relva crescer, uma metáfora que revelava o crescimento e amadurecimento do grupo, pois, segundo Itman Monteiro, "[...] cada instituição é única, cada sala de aula se compóe de modo diferenciado, cada microgrupo é inédito e cada pessoa que ali desenha a cena, quer seja situando-se em seu centro ou em suas margens, emoldura o cotidiano imprimindolhe uma nova matriz num jogo de luzes e sombras" (2005, p. 142). Neste sentido, o que contemplávamos era o espaço de integração e a promoção da socialidade e sensibilidade que envolvia os participantes por meio do brincar e do jogar prazerosamente, o que resultou em ressignificar e reencantar o espaço do Galpáo Escola Presídio e suas vidas.

Portanto, a oficina possibilitou uma prática pedagógica sensível, uma vez que, amparada na ciência e na arte, contemplava a razão e a imaginação ao reinterpretar as práticas simbólicas educativas, possibilitando a visibilidade necessária e permitindo, com isso, o aflorar de mitos, rituais, sonhos, medos e histórias de vida e, então, 
permitindo-nos pensar que esses elementos nos trazem pistas para a constituição de novos saberes destinados à formação da pessoa, visto que contemplam um saber-fazer, saber-dizer e saber-viver.

A realização dessa experimentação a partir da oficina d'O Brincar com Teatro junto aos monitores pôde proporcionar reflexóes entre nós, na medida em que o envolvimento e a satisfaçáo do ato de jogar (jogos tradicionais e teatrais) possibilitaram promover, diante deles, o conhecimento de si, do outro e do mundo; a expressão corporal/ vocal espontânea; a sensibilidade; a curiosidade; o espírito de equipe; o ser social; e o processo de criaçáo com o teatro por meio dos jogos expressos em suas narrativas, desenhos e improvisaçóes teatrais.

Nesses encontros, as brincadeiras e cantigas como um exercício de pré-aquecimento, levou em conta o prazer e a satisfaçáo do brincar e jogar com o teatro. Assim, os encontros tinham o intuito de despertar a sensibilidade de si e do outro a partir do teatro para possibilitar uma formação ampla da pessoa por meio de uma prática que contemplava a escutar de si as descobertas, o corpo, a sociabilidade (estar-junto), as angústias, a liberdade de expressão e a imaginação para tornar o detento uma pessoa mediante a sua condiçáo atual, isto é, privada de sua liberdade. 


\section{Notas}

${ }^{1}$ Compartilho da ideia do pesquisador Gilberto Icle quando nos diz brilhantemente que um professor-artista suporia um professor-criador, um artista na escola, uma escola com arte, uma aula $\mathrm{em}$ arte, antes que uma aula sobre arte (Icle, 2012, p. 18). Essa é a mesma visão que pensarei quando remeter a esse termo, professor-artista, particularmente, professorartista de teatro.

${ }^{2}$ Tomo aqui as palavras da pesquisadora Lima e Gomes ao explicar a noção de corpo para Maffesoli, ou seja, "[...] no dizer de Maffesoli, corpo social tem sido uma metáfora sem sentido: é preciso integrar esse corpo social. Para entender agrupamentos - tribos -, é preciso compreender o sensível. A ideia de corpo, para o autor, parece ser de um corpo sensível ou sensorial, um corpo lúdico e dionisíaco. É corpo de um Homo estheticus: o homem que 'serve a' e que 'se serve'. O estético, com Maffesoli, tem como referente aisthesis, experimentar com o outro alguma coisa" (2000, p. 26).

${ }^{3}$ Morin apresenta quatro teses já bem conhecidas entre nós acerca desse paradigma emergente: 1) todo o conhecimento científico-natural é científico-social. O conhecimento do paradigma emergente tende a ser um conhecimento não dualista, um conhecimento que se funda na superação das distinções tão familiares e óbvias que até há pouco tempo considerávamos insubstituíveis, tais como natureza/cultura, natural/artificial, vivo/inanimado, mente/ matéria, observador/observado, subjectivo/objectivo, coletivo/indivíduo, animal/pessoa (2007, p. 39); 2) todo conhecimento é local e total. No paradigma emergente, o conhecimento é total, tem como horizonte a totalidade indivisa de que fala Bohm. Mas sendo total, é também local. Constitui-se em redor de temas; em dado momento, são adoptados por grupos sociais concretos como projecto de vida locais $(2007$, p. 47);3) todo conhecimento é autoconhecimento. Por isso, todo o conhecimento científico é autoconhecimento. A ciência não descobre, cria e o acto criativo protagonizado por cientista e pela comunidade científica no seu conjunto tem de se conhecer intimamente antes que conheça o que com ele se conhece do real (2007, p. 52); e, por fim, 4) todo conhecimento científico visa constituir-se em senso comum. A mais importante de todas é o conhecimento de senso comum, conhecimento vulgar e prático com que o quotidiano orientamos as nossas acçóes e damos sentido à nossa vida. A ciência moderna construiu-se contra o senso comum que considerou superficial, ilusório e falso. A ciência pós-moderna procura reabilitar o senso comum por reconhecer nesta forma de conhecimento algumas virtualidades para enriquecer a nossa relaçáo com o mundo (2007, p. 56).

${ }^{4}$ Conforme Angrosino, a observação é o ato de perceber as atividades e os interrelacionamentos das pessoas no cenário de campo através dos cinco sentidos; a pesquisa em arquivo é a análise de materiais que foram guardados para pesquisa, serviço e outros objetivos, oficinas ou não; e, por fim, a entrevista é um processo que consiste em dirigir a conversação de forma a colher informaçôes relevantes (2009, p. 56-61).

${ }^{5}$ Conforme Vasconcelos, a observaçáo participante gira em torno da tentativa de tornar significativo o mundo (a ser) estudado na perspectiva dos que estão a ser observados. Para tanto, considera que observador-participante ocupa de uma situação social com dois objetivos: por um lado, inserir-se nas atividades intrínsecas a essa situação e, por outro lado, observar as atividades, as pessoas e mesmo os aspectos físicos dessa mesma situação (2006, p. 93). 
${ }^{6}$ Neste sistema penitenciário, existem dois presídios caracterizados como presídio I e presídio II. O meu terreno de investigação foi o presídio II.

${ }^{7}$ Após a minha contratação pela FUNAP, elaborei uma proposta de trabalho a partir da temática do Brincar com Teatro com objetivo de possibilitar aos detentos o prazer de jogar cenicamente a partir dos jogos (tradicionais e teatrais). Contemplei, também, trabalhar o teatro enquanto possibilidade para a prática pedagógica com os monitores, uma vez que eles lecionavam para outros detentos nesse Galpão Escola.

${ }^{8}$ Diz Goffman: “[...] Geralmente, o processo de admissão também leva a outros processos de perda e mortificação [...] obter uma historia de vida, tirar fotografia, pesar, tirar impressóes digitais, atribuir números, procurar e enumerar bens pessoais para que sejam guardados, despir, dar banho, desinfetar, cortar os cabelos, distribuir roupas da instituição, dar instruçóes quanto a regra, designar um local para o internado" (1987, p. 25).

${ }^{9}$ Para Pavis, skênê, em grego, significa barraca, tablado, e possui relação com a cena, pois uma peça ou uma passagem são, às vezes, particularmente cênicas, isto é, espetaculares, facilmente realizáveis e representáveis (1999, p. 42-4).

${ }^{10}$ Entendo encenação em práticas educativas como um processo de investigação, comunicação e criaçáo a partir do interesse dos participantes em realizar tal experiência estética da linguagem cênica, tendo como foco a relação de um processo de aprendizagem em relação palco-plateia.

${ }^{11}$ Os exercícios iniciavam sempre por meio das brincadeiras dos jogos tradicionais, que tinha também o objetivo de aquecer o material humano, isto é, o corpo/voz. Em seguida, partia para a aprendizagem dos jogos teatrais inspirando-se em Spolin (1992) e Koudela (1992) no que tange aos elementos da estrutura dramática (onde? quem? o quê?), do foco, da fiscalização e da avaliação.

${ }^{12}$ Conforme Delory-Momberger, nós, seres humanos, apropriamo-nos de nossa vida e de nós mesmos por meio de história, pois tanto na linguagem coloquial quanto nas criaçóes mais elaboradas, nós recorremos sempre entre as palavras e as imagens para transpor, numa representação espacial, o desenvolvimento temporal da nossa existência, uma vez que linha, fio, caminho, trajeto, estrada, percurso, círculo, carreira, ciclo de vida possibilitam escrever, no espaço, a figura da nossa vida. Assim, quando queremos nos apropriar de nossa vida, nós a narramos. O único meio de termos acesso a nossa vida é percebermos o que vivemos por intermédio da escrita de uma história (ou de uma multiplicidade de histórias): de certo modo, só vivemos nossa vida escrevendo-a na linguagem das histórias (Delory-Momberger, 2008, p. 36).

\section{Referências}

ANGROSINO, Michel. Etnografia e Observação Participante. Porto Alegre: Artmerd, 2009.

BAUER, Martin; GASKELL, George. Pesquisa Qualitativa com Texto, Imagem e Som. Um manual prático. Petrópolis: Vozes, 2008. 
BENJAMIN, Walter. Reflexóes: a criança, o brinquedo, a educação. São Paulo: Summus, 1984.

CARAÇA, João. Ciência. Coimbra: Quimera, 2001.

CARVALHO, José Carvalho Paula. Paradigma do Imaginário e Educação Fática: contribuiçóes filosóficas e antropológicas. In: SANCHEZ TEIXEIRA, Maria Cecília; PORTO, Maria do Rosário Silveira (Org.). Imagens da Cultura: um outro olhar. São Paulo: Plêiade, 1999.

COLI, Jorge. O que é Arte. São Paulo: Brasiliense, 2000.

DELORY-MOMBERGER, Christine. Biografia e Educação. Natal/São Paulo: EDUFRN/ Paulus, 2008. (Coleção Pesquisa (auto)biográfica Educação.)

ERNY, Pierre. Etnologia da Educação. Rio de Janeiro: Zahar, 1982.

FOUCAULT, Michel. Vigiar e Punir: história da violência nas prisões. Petrópolis: Vozes, 1987.

GOFFMAN, Erving. Manicômios, Prisóes e Conventos. São Paulo: Perspectiva, 1987.

ICLE, Gilberto. O Ator como Xamã: configurações da consciência no sujeito extracotidiano. São Paulo: Perspectiva, 2010.

ICLE, Gilberto (Org.). Pedagogia da Arte: entre-lugares da escola. Porto Alegre: UFRGS, 2012.

ITAMAN MONTEIRO, Sueli Aparecida. Cultura Escolar e Imaginário. In: SOUZA, Rosa Fátima de; VALDEMARIN, Vera Teresa. A Cultura Escolar em Debate: questóes conceituais, metodológicas e desafios para a pesquisa. Campinas: Autores Associados, 2005. P. 141-155.

ITAMAN MONTEIRO, Sueli Aparecida. Luzes, Sombras e Crepúsculos nas Vivências Cotidianas de Duas Escolas de Primeiro Grau: sucessos, fracassos, evasões, exclusóes. 1996. Tese (Doutorado em Educação) - Programa de Pós-gradução em Educação, Faculdade de Educaçáo, Universidade de São Paulo, Sáo Paulo, 1996.

KOUDELA, Ingrid Dormien. Jogos Teatrais. São Paulo: Perspectiva, 1992.

LAPLANTINE, François. A Descrição Etnográfica. São Paulo: Terceira Margem, 2004. LIMA E GOMES, Icléia Rodrigues. A Escola como Espaço de Prazer. São Paulo: Summus, 2000.

LIMA, Avila de; PACHECO, José Augusto. Fazer Investigação. Contributos para a elaboração de dissertaçóes e teses. Portugal: Porto, 2006.

LISPECTOR, Clarice. A Paixáo segundo G. H. Rio de Janeiro: Rocco, 1998.

MACEDO, Roberto Sidnei. A Etnopesquisa Crítica e Multirreferencial: nas ciências humanas e na educação. Salvador: EDUFBA, 2000.

MAFFESOLI, Michel. Elogio da Razão Sensível. Petrópolis: Vozes, 1998. 
MORIN, Edgar. Introdução ao Pensamento Complexo. Lisboa: Instituto Piaget, 2008. OLIVEIRA, Inês Barbosa; SGARBI, Paulo. Estudo do Cotidiano e Educação. São Paulo: Autêntica, 2008.

PAVIS, Patrice. Dicionário de Teatro. São Paulo: Perspectiva, 1999.

SANCHEZ TEIXEIRA, Maria Cecília; SILVEIRA PORTO, Maria Rosário. Perspectivas Paradigmáticas em Educação. Revista da Faculdade de Educação, São Paulo, Universidade de São Paulo, v. 21, n. 1, jan./jun. 1995.

SPOLIN, Viola. Improvisação para o Teatro. São Paulo: Perspectiva, 1992.

TELlES, Narcísio (Org.). Pesquisa em Artes Cênicas: textos e temas. Rio de Janeiro: E-papers, 2012.

Micael Côrtes é ator, professor-pesquisador no campo da Pedagogia do Teatro. Professor do curso de Licenciatura Plena em Artes Cênicas: Teatro e do Programa de Pós-graduação em Linguagem e Identidade da Universidade Federal do Acre (UFAC), onde lidera o Grupo de Investigação Teoria-Prática Teatral - GIPT. Em 2013, apresentou o trabalho investigativo As Criadas de Jean Genet. Doutor em Educação pela Universidade Estadual Paulista (UNESP).

E-mail: micaelcortes@yahoo.com.br

Recebido em 18 de fevereiro de 2013 Aceito em 03 de janeiro de 2014 